\title{
E-KÖNYVEK KONZORCIÁLIS BESZERZÉSE - E-KÖNYVEK MEGJELENÉSE AZ EISZ NeMZETI PROGRAMBAN
}

\author{
Lencsés Ákos \\ MTA Könyvtár és Információs Központ EISZ Titkárság (grid.496758.1) \\ ORCID: 0000-0003-4461-1105
}

DOI: 10.31915/NWS.2018.10

\begin{abstract}
E-book acquisition in the Electronic Information Service National Programme (EIS) The Electronic Information Service National Programme (EIS) is the national consortium of Hungary. The consortium subscribes more than 50 databases each year, however e-book acquisition is a rather new phenomenon in the programme.

The paper focuses on how to introduce e-book acquisition models in consortium level, what workflow is necesseary for the e-book acquisition and what new services can EIS implement to help the consortium members regarding e-book collections.
\end{abstract}

Keywords: library consortium, e-book acquisition, patron-driven acquisition (PDA), evidence-based acquisition (EBA), e-book purchase

\section{Bevezetés}

A könyvtárak állománygyarapítási tevékenységében napjainkban elengedhetetlenek az online források. Az elmúlt évtizedekben az adatbázisok előfizetését az intézmények az esetek nagy részében konzorciumi keretek között végezték. Ennek speciális formája a nemzeti konzorcium, amelynek során az adott ország valamennyi könyvtára egy konzorciumi vezetőn keresztül tárgyal a szolgáltatókkal, és végzi az előfizetést. Az online világban elsődlegesen a folyóirat-adatbázisok jelentek meg, kialakult a Big Deal, amelynek keretében egy kiadó összes vagy jelentős számú folyóiratára kedvezményesen fizethetnek elő a konzorciumok. A folyóirat-adatbázisokat követve kezdtek elterjedni az e-könyvek és az e-könyveket kínáló adatbázisok. A folyóiratok és a könyvek kezelése nemcsak a nyomtatott világban tér el egymástól, de az online világban is számtalan különbség figyelhetö meg a két dokumentumtípus beszerzése, használata és kezelése között. Az alábbiakban a teljesség igénye nélkül összefoglaljuk a legfontosabb jellemzőket, amelyekre az e-könyv-beszerzés során figyelemmel kell lenni.

\section{E-könyv-használati feltételek}

A folyóirat-adatbázisoknál általában előfizetésről beszélünk, tehát az előfizetés évében férnek hozzá a felhasználók az abban és a korábbi években megjelent folyóiratszámokhoz. Az e-könyvek esetén is található elöfizetéses konstrukció, de ennél jóval gyakoribb az „örökáras” vásárlás, amelynek során a kiadványok örök használatra a könyvtár állományába kerülnek. Így ezekben az esetekben „árubeszerzésről” van szó, nem szükséges az előfizetést minden évben meghosszabbítani.

A folyóirat-adatbázisoknál általában egyszerre korlátlan felhasználó férhet hozzá az előfizetett tartalmakhoz. Az e-könyveknél sok esetben fontos árbefolyásoló tényező az, hogy egyszerre 1, 3, 5 vagy korlátlan számú felhasználó tudja megnyitni a kiadványokat. Előfordulhat kreditalapú megoldás is. 


\section{NETWORKSHOP 2018}

Kreditalapú rendszernél az előfizető intézmény az adott évben 300 (vagy tetszőleges számú) kreditet vásárol, és így a felhasználók az év során 300 alkalommal tudják megnyitni a kiadványt. Ez a konstrukció kedvező lehet olyan kötetek esetén, amelyeket a vizsgaidőszakban egyszerre egész évfolyamnyi diák szeretne online megnyitni, de az év más időszakaiban nem jelentkezik rájuk intenzív felhasználói igény.

A folyóirat-adatbázisoknál az egyes cikkek kinyomtatása, lementése az esetek túlnyomó részében biztosított. Az e-könyv-beszerzéseknél fontos szempont ezeknek a kérdéseknek a tisztázása: az e-könyvek DRM-mentesek vagy sem. Kiadónként, csomagokonként vagy akár kiadványonként is eltérő lehet az, hogy egyes e-könyvek mekkora része nyomtatható. A skála széles a teljes dokumentum nyomtathatóságától a százalékosan vagy szám szerint meghatározott nyomtatható oldalszámon át a nyomtatás teljes szoftveres tiltásáig. Hasonlóan széles skála figyelhető meg a dokumentum elmenthetőségére vonatkozóan. Különösen szépirodalmi e-könyv-csomagok esetén fontos kérdés lehet az e-könyvek kölcsönözhetőségére vonatkozó feltétel is.

A folyóirat-adatbázisok esetén szinte kizárólag PDF - és ritkábban HTML - formátumú dokumentumok fordulnak elő. Az e-könyveknél is a PDF a leggyakoribb, azonban előfordulhatnak ePUB, MOBI vagy más e-könyves formátumok is. Ez utóbbi formátumok különösen a szépirodalmi és más közkönyvtári e-könyvcsomagoknál szerepelhetnek.

Az e-könyv-használat további sajátosságait - elsősorban a közkönyvtári vonatkozással - korábban Muzs Krisztina foglalta össze. ${ }^{1}$

\section{E-könyv-beszerzési eljárások}

Az e-könyvek esetén gyakoriak az egyszeri beszerzéssel járó, egy-egy címre vagy e-könyv-csomagokra vonatkozó vásárlások, és jóval ritkábbak az előfizetéses konstrukciók. Az online világban ezek mellett olyan beszerzési lehetőségek is kialakultak, amelyek gyökeresen eltérnek a folyóirat-adatbázisoknál megszokott eljárásoktól.

A felhasználói igény alapján irányított beszerzés (patron-driven acquisition, PDA) során az intézmény a megállapodott összeg fejében a meghatározott időszakra hozzáfér a kiadó teljes vagy az intézmény szempontjából releváns e-könyv-állományához. Az adatbázis használata során a gyakran igénybe vett dokumentumokazelöre befizetettösszeg erejéig megvásárlásra kerülnek. Ezeketakésőbbiekben márnem előfizetéses konstrukció keretében lehet használni, hanem örökre az intézmény állományába kerülnek. A felhasználók így tudtukon kívül a dokumentumok használata során elvégzik az állománygyarapítási munkafolyamatok egy részét. Ez az eljárás biztosítja azt az intézmények számára, hogy a kiadó kínálatából kizárólag a felhasználók által ténylegesen igénybe vett dokumentumokat vásárolják meg. A folyamatban

1 Muzs Krisztina, ,E-könyvek a könyvtárakban. 1. rész,” Tudományos és Müszaki Tájékoztatás 62, 1. Sz. (2016): 3-26. 
az intézmény munkatársai a szolgáltatóval egyeztetve elöre meghatározzák, hogy egy adott könyv milyen feltételek mellett kerül megvásárlásra. Több más szempont mellett ilyen tényező lehet a megnyitások száma (pl. három megnyitás után a könyvtár automatikusan megvásárolja a kiadványt) vagy a megnyitás időtartama (pl. a könyv automatikusan megvásárlásra kerül, ha már fél órát olvasták). A felhasználói igény alapján irányított beszerzés során kiemelten fontos, hogy a felhasználók ne tudjanak az eljárásról; ez biztosítja, hogy a tényleges felhasználói szokások torzítás nélkül irányítsák a beszerzéseket. A beszerzés során előfordulhat egy-egy kiadó teljes e-könyv-portfóliójának a megnyitása, de az intézménnyel egyeztetve gyakori az is, hogy az előfizetői profilba vágó kiadványokat teszik hozzáférhetővé. Ezzel elkerülhető, hogy egy orvosi egyetemen az automatikus vásárlás miatt más tudományterület kiadványait vásárolják meg nagy számban. Az előzetes beállítások során rögzíthető az egy e-könyvre jutó összeg felső határa is, pl. beállítható, hogy 200 eurónál drágább könyvet nem vásárol meg automatikusan az intézmény, csak a könyvtáros jóváhagyása után.

A használati adatok alapján történö beszerzés (evidence-based acquisition, EBA) esetén az intézmény meghatározott időre előfizet a szolgáltató e-könyv-csomagjára. Az előfizetési idő végén az intézmény a használati adatok alapján kiválaszthatja azokat az e-könyveket, amelyeket a korábban előfizetési díjként befizetett összeg értékében szeretne megvásárolni és állományába olvasztani. A felhasználói igény alapján irányított beszerzéssel ellentétben ez az eljárás lehetőséget biztosít az intézmény munkatársainak arra, hogy finomhangolást hajtsanak végre a vásárlás előtt. Í Így elkerülhető olyan könyvek beszerzése, amelyekre a következő években nem lesz szükség (pl. az adott kurzus megszünése miatt), illetve beemelhetők olyan tételek, amelyek használata nem volt jelentős, de kutatói, oktatói igény alapján indokolt a beszerzésük (pl. a következő tanévben induló új kurzus hallgatói számára). A szolgáltatóval történő előzetes egyeztetés során meghatározható az előfizetési idő (általában egy év, ritkább esetben fél év vagy más időtartam) és az előfizetett e-könyv-csomagok köre az intézményi profil alapján. Az elöfizetési idő lejárta után az intézménynek természetesen lehetősége nyílikújabb összeg befizetésével az előfizetési díjon felül további kiadványok megvásárlására is, amennyiben a beszerzési szempontok indokolják nagyobb számú e-könyvek megvásárlását.

A két bemutatott beszerzési eljárás az előfizetés és a vásárlás ötvözéseként született meg. Mindkét módszer esetén a legfőbb cél az volt, hogy az állománygyarapítási döntéseket segítse, és elkerülhetővé tegye az intézmények számára a „fölösleges” címek beszerzését. Rebecca Schroeder és Rebecca Boughan kiemelik a több e-könyv-beszerzési modell párhuzamos alkalmazásának hatékonyságát is. ${ }^{3}$ Melissa De Fino és Mei Ling Lo hangsúlyozzák a beszerzési mód könyvtári rendszerbe történő integrálását - beleértve a kiadványok katalógusban történő szerepeltetését, a megfelelő MARC-mezők kiválasztását, a használat növekedését elősegítő kommunikációs stratégia kialakítását. ${ }^{4} \mathrm{~A}$ bemutatott két módszer

$2 \quad$ Hilary Robbeloth, Matthew Ragucci és Kristina M. Deshazo, ,„Evidence-Based Acquisition: A Real Life Account of Managing the Program Within The Orbis Cascade Alliance," Serials Librarian 73, 3-4. sz. (2017): $240-247$.

3 Rebecca Schroeder, Rebecca Boughan. „Adoption of a Comprehensive E-book Acquisition Strategy to Increase Return on Investment While Containing Costs," Library Resources and Technical Services 62, 1. sz. (2018): 28-36.

$4 \quad$ Melissa De Fino, Mei Ling Lo. „New Roads for Patron-Driven E-Books: Collection Development and Technical Services Implications of Patron-Driven Acquisitions Pilot at Rutgers," Journal of Electronis Resources Librarianship 23, 4. sz. (2011): 327-338. 


\section{NETWORKSHOP 2018}

fontos szempontja a használati adatok értékelése a beszerzés során. Ehhez kellő mértékű használatra van szükség, így a könyvtárosoknak mindenképpen szerepet kell vállalniuk az elérhető kiadványok népszerüsítésében a meghatározott időszakban.

\section{E-könyvek az EISZ Nemzeti Programban}

Az Elektronikus Információszolgáltatás (EISZ) Nemzeti Program keretében 2018-ban kétszáz intézmény férhet hozzá több mint 50 adatbázishoz. A program az elmúlt tizenöt évben elsősorban folyóiratadatbázisok konzorciumi elöfizetésével segítette a hazai kutatói közösséget és a könyvtárakat. Az intézmények részéröl azonban egyre nagyobb igény jelentkezett e-könyvek beszerzésére is. Egyes adatbázisok esetén a folyóiratok mellett e-könyvek is szerepeltek, azonban önálló e-könyv-csomag beszerzése konzorciumi keretek között nem zajlott eddig az EISZ segítségével. Az EISZ szerepét az állománygyarapításban Dér Ádám és Lencsés Ákos mutatta be. ${ }^{5}$ Az egyéni e-könyv-beszerzés intézményi tapasztalatairól Ruttkay Szilvia tartott előadást a 3. Szakkönyvtári Seregszemle konferencián. ${ }^{6}$

2017 végén a nemzeti programban részt vevő intézmények számára próbajelleggel lehetőség nyílt a Springer Nature, az Institute of Physics (IOP) és a Royal Society of Chemistry (RSC) e-könyv-csomagjainak megrendelésére. A csomagok iránt a vártnál is nagyobb volt az érdeklődés: 17 intézmény vásárolt Springer e-könyveket, összesen 234976 értékben. Ennek az összegnek a felét fizették az intézmények, a másik felét az EISZ Nemzeti Program vállalta magára. Valamennyi Springer e-könyv-csomag a 2017-ben megjelent (CY2017) kiadványokat foglalja magában. A vásárlást követően a könyvcsomagok címlistája hozzáférhető a COMPASS adatbázisban is (http://compass.mtak.hu), így a COMPASS folyóiratcímek mellett korlátozott mértékben már e-könyvek országos lelőhely-meghatározásához is használható.

\section{A megvásárolt Springer e-könyv-csomagok listája}

\begin{tabular}{|l|l|}
\hline \multicolumn{2}{|c|}{ Andrássy Gyula Budapesti Német Nyelvü Egyetem } \\
\hline Business and Management & Political Science and International Studies \\
\hline Economics and Finance & Religion and Philosophy \\
\hline Education & Social Sciences \\
\hline History & Wirtschaftswissenschaften \\
\hline Law and Criminology & Sozialwissenschaften und Recht \\
\hline Literature, Cultural and Media Studies & J.B. Metzler Geisteswissenschaften \\
\hline
\end{tabular}

\section{Budapesti Corvinus Egyetem}

\begin{tabular}{|l|l|}
\hline Behavioral Science and Psychology & Political Science and International Studies \\
\hline Economics and Finance & \multicolumn{1}{|l|}{} \\
\cline { 1 - 2 } &
\end{tabular}

5 Dér Ádám, Lencsés Ákos, „Az EISZ Nemzeti Program szerepe a könyvtárak külföldi szakirodalommal való ellátásában,” Tudományos és Müszaki Tájékoztatás 64, 5. sz. (2017): 241-246.

6 Ruttkay Szilvia. „E-könyvek, online könyvek... Mit tud(hat)unk róluk? Intézményi beszerzések tapasztalatairól röviden," közzétéve 2018. március 15-én, videó, 21:02, http://kshkonyvtar.videotorium.hu/hu/recordings/19302/e-konyvek-online-konyvek 


\begin{tabular}{|l|l|}
\hline \multicolumn{2}{|c|}{ Budapesti Müszaki és Gazdaságtudományi Egyetem } \\
\hline Business and Management & Energy \\
\hline Chemistry and Materials Science & Engineering \\
\hline Computer Science & Mathematics and Statistics \\
\hline Economics and Finance & \multicolumn{2}{|l}{} \\
\cline { 1 - 2 }
\end{tabular}

\begin{tabular}{|l|l|}
\hline \multicolumn{2}{|c|}{ Debreceni Egyetem } \\
\hline Business and Management & Economics and Finance \\
\hline Earth and Environmental Science & Medicine \\
\hline
\end{tabular}

\begin{tabular}{|l|l|}
\hline \multicolumn{2}{|c|}{ Eötvös Loránd Tudományegyetem } \\
\hline Behavioral Science and Psychology & Law and Criminology \\
\hline Computer Science & Mathematics and Statistics \\
\hline Earth and Environmental Science & Political Science and International Studies \\
\hline Education & Religion and Philosophy \\
\hline History & Social Sciences \\
\hline
\end{tabular}

\begin{tabular}{|l|l|}
\hline \multicolumn{2}{|c|}{ Eszterházy Károly Egyetem } \\
\hline Computer Science & Education \\
\hline
\end{tabular}

\section{Közép-európai Egyetem}

\begin{tabular}{|l|l|}
\hline Political Science and International Studies & Social Sciences \\
\hline Religion and Philosophy & \multicolumn{1}{|c}{} \\
\cline { 1 - 2 }
\end{tabular}

\section{Magyar Honvédség Egészségügyi Központ}

Medicine

\begin{tabular}{|l|l|}
\hline \multicolumn{2}{|c|}{ Magyar Müvészeti Akadémia } \\
\hline History & Religion and Philosophy \\
\hline Literature, Cultural and Media Studies & Social Sciences \\
\hline
\end{tabular}

\section{MTA Csillagászati és Földtudományi Kutatóközpont}

Earth and Environmental Science

\section{MTA Szegedi Biológiai Kutatóközpont}

\begin{tabular}{|l|l|}
\hline Biomedical and Life Sciences & Mathematics and Statistics \\
\hline Chemistry and Materials Science & \multicolumn{1}{|l}{} \\
\cline { 1 - 2 }
\end{tabular}

\section{MTA Wigner Fizikai Kutatóközpont}

\begin{tabular}{|l|l|}
\hline Chemistry and Materials Science & Physics and Astronomy
\end{tabular} 
NETWORKSHOP 2018

\begin{tabular}{|l|l|}
\hline \multicolumn{2}{|c|}{ Nemzeti Közszolgálati Egyetem } \\
\hline Law and Criminology & Sozialwissenschaften und Recht \\
\hline Political Science and International Studies &
\end{tabular}

\begin{tabular}{|l|l|}
\hline \multicolumn{2}{|c|}{ Pécsi Tudomyegyetem } \\
\hline Behavioral Science and Psychology & Literature, Cultural and Media Studies \\
\hline Business and Management & Political Science and International Studies \\
\hline Economics and Finance & Social Sciences \\
\hline Law and Criminology & \multicolumn{2}{|l}{} \\
\cline { 1 - 2 } &
\end{tabular}

\section{Semmelweis Egyetem}

\begin{tabular}{|l|l}
\hline Behavioral Science and Psychology & Social Sciences
\end{tabular}

\begin{tabular}{|l|l|}
\hline \multicolumn{2}{|c|}{ Szegedi Tudományegyetem } \\
\hline Biomedical and Life Sciences & Medicine \\
\hline Engineering & J.B. Metzler Geisteswissenschaften \\
\hline Law and Criminology & \multicolumn{1}{|c|}{} \\
\cline { 1 - 2 } &
\end{tabular}

\begin{tabular}{|l|l|}
\hline \multicolumn{2}{|c|}{ Szent István Egyetem } \\
\hline Biomedical and Life Sciences & Earth and Environmental Science \\
\hline Business and Management & Economics and Finance \\
\hline Chemistry and Materials Science & \multicolumn{2}{|l}{} \\
\cline { 1 - 2 } &
\end{tabular}

A próbajellegü beszerzés ismét rámutatott az e-könyvek iránti fokozódó érdeklődésre. Az eredmények után az EISZ Titkárság munkatársai 2018. január 25-26-án szakmai napot szerveztek, hogy tájékozódjanak az intézmények tapasztalatairól és igényeiről. A találkozón részt vettek a Budapesti Corvinus Egyetem, a Debreceni Egyetem, az Eötvös Loránd Tudományegyetem, a Közép-európai Egyetem, a Központi Statisztikai Hivatal Könyvtár, az MTA Csillagászati és Földtudományi Kutatóközpont, az MTA Wigner Fizikai Kutatóközpont, a Pécsi Tudományegyetem, a Semmelweis Egyetem és a Szegedi Tudományegyetem munkatársai.

A szakmai napon többek között megfogalmazódott, hogy az intézmények igénylik az e-könyv-kínálat bővülését. Az is kiderült, hogy a konzorciumi beszerzés a tárgyalási pozíciót is jelentősen javítja: a Springer Nature képviselői korábban az igények ellenére sem biztosítottak az intézmények számára olyan kisebb, szakterületi csomagokat tartalmazó e-könyves ajánlatot, mint az EISZ-en keresztül. 
A résztvevők egyetértettek abban, hogy a címenként történő vásárlás nem alkalmas konzorciumi beszerzésre, ugyanakkor nyitottak a felhasználói igény alapján irányított beszerzési mód és a használati adatok alapján történő beszerzési mód kipróbálására. Ezek az eljárások azonban több jogi kérdést is felvetnek, hiszen a folyamat elején még nem lehet meghatározni azt, hogy milyen e-könyvek kerülnek a végén az intézmények tulajdonába. A jogi keretek adta mozgástér tisztázásáig a nemzeti programon keresztül e-könyv-csomagok örökáras vásárlására nyílik lehetőség. A kezdeti időszakban kizárólag kiadói e-könyv-csomagok szerepelnek a nemzeti programban, tehát aggregátor cégek (EBSCO, ProQuest stb.) e-könyves ajánlatainak befogadására nincs lehetőség.

A szakmai napon egyeztetett álláspont szerint az e-könyves portfólió bővülésére a Cambridge University Press (CUP), a De Gruyter, az IOP, az Oxford University Press (OUP), az RSC, a Springer Nature, a Taylor \& Francis és a Wiley kiadványai lennének a legalkalmasabbak. Az EISZ Titkárság munkatársai a kiadókkal történő egyeztetés után a 2019-re vonatkozó igényfelmérésben a De Gruyter, az IOP, az RSC, a Springer Nature és a Wiley e-könyv-csomagjait szerepeltették. Az e-könyves igényfelmérés az éves, adatbázisokra vonatkozó igényfelméréssel párhuzamosan zajlott - nem keverve az előfizetésre és a vásárlásra kínált tartalmakat.

\section{Összegzés}

Az e-könyvekre vonatkozó munkafolyamatok több helyen eltérhetnek a folyóirat-adatbázisoknál megszokott eljárásoktól. Az intézményi visszajelzések alapján egyértelmű az e-könyvekre vonatkozó igények növekedése a kutatói közösség részéről. Az EISZ Nemzeti Programban lépésről lépésre haladva, az intézményekkel történő folyamatos egyeztetés mellett jelennek meg az e-könyvek - abban bízva, hogy minden érintett intézmény számára segítséget jelent ez a lehetőség.

\section{Bibliográfia}

De Fino, Melissa, Mei Ling Lo. „New Roads for Patron-Driven E-Books: Collection Development and Technical Services Implications of a Patron-Driven Acquisitions Pilot at Rutgers." Journal of Electronic Resources Librarianship 23, 4. Sz. (2011): 327-338. https://doi.org/ 10.1080/1941126X.2011.627043

Dér Ádám, Lencsés Ákos. „Az EISZ Nemzeti Program szerepe a könyvtárak külföldi szakirodalommal való ellátásában." Tudományos és Müszaki Tájékoztatás 64, 5. sz. (2017): 241-246.

Muzs Krisztina. „E-könyvek a könyvtárakban. 1. rész.” Tudományos és Müszaki Tájékoztatás 62, 1. sz. (2016): 3-26. 


\section{NETWORKSHOP 2018}

Robbeloth, Hilary, Matthew Ragucci és Kristina M. Deshazo. „Evidence-Based Acquisition: A Real Life Account of Managing the Program Within The Orbis Cascade Alliance." Serials Librarian 73, 3-4. sz. (2017): 240-247. https://doi.org/10.1080/0361526X.2017.1388331

Ruttkay Szilvia. „E-könyvek, online könyvek... Mit tud(hat)unk róluk? Intézményi beszerzések tapasztalatairól röviden." Közzétéve 2018. március 15-én. Videó, 21:02. http://kshkonyvtar.videotorium. hu/hu/recordings/19302/e-konyvek-online-konyvek.

Schroeder, Rebecca, Rebecca Boughan. „Adoption of a Comprehensive E-book Acquisition Strategy to Increase Return on Investment While Containing Costs." Library Resources and Technical Services 62, 1. sz. (2018): 28-36. https://doi.org/10.5860//rts.62n1.28 